\title{
EVALUATION OF THE RESISTANCE CRITICAL INFRASTRUCTURE IN SLOVAK REPUBLIC
}

\author{
Zdeněk DVOŘÁK ${ }^{1}$, Eva SVENTEKOVÁ ${ }^{2}$ \\ ${ }^{1}$ Research Department of Crisis Management, Faculty of Special Engineering, University of Zilina, st. Majova 32, 010 \\ 26 Zilina, Slovakia \\ ${ }^{2}$ Faculty of Special Engineering, University of Zilina, st. Majova 32, 01026 Zilina, Slovakia. Corresponding author. E- \\ mail: Eva.Sventekova@fsi.uniza.sk
}

Accepted 27 October, 2011

\begin{abstract}
Evaluation of resilience of critical infrastructure designed in Slovakia so far only acted on critical infrastructure, which was approved by the National Council 08/02/2011. So far, not in the legal system, have been defined ways of assessing the resistance of KI. The following sections are created by the authors based on their knowledge and consultations of the Ministries of Interior and Transport, Construction and Regional Development.
\end{abstract}

Keywords: critical infrastructure, evaluation, resistance, criticality.

\section{INTRODUCTION}

Field evaluation of critical infrastructure has been the subject of debate in recent years, policy decisions and the content of the research tasks. The Slovak Republic ranks among the states with a developed economy, this creates the requirements associated with its technical and technological strength of sophistication. An important part of the functionality of the systems is to ensure the availability of energy and raw materials necessary for the operation of the production, the supply of goods and services. These conditions of the existence of economic, but also social system of the state have some links that may be critical. The extent of criticality of certain infrastructure creates its impact in terms of consequences to own functionality of service, product or functionality to other systems or infrastructure. This article presents the results of scientific research at the Faculty of Special Engineering, University of Zilina.

\section{INTERNATIONAL FRAME OF CRITICAL INFRASTRUCTURE ASSESSMENT}

International calls and experiences give wide range of methods for risk assessment. Next information is modified by source - "Report of Institute for the protection and security of the citizen". The most important methods and expert information systems include:

- The US-Canadian expert system CARVER (Criticality, Accessibility, Recoverability, Vulnerability, Effect, Redundancy)

- American system MSHARPP (Mission, Symbolism, History, Accessibility, Recognizability, Population, Proximity)

- Concept - PSRAT (Port Security Risk Assessment Tool)

- Concept - VI (Vulnerability Index)

- Concept - PMI (Protective Measures Index)

- Concept - RI (Resilience Index)

Examination of the criticality of critical infrastructure is a very actual issue. Many countries around the world create a variety of methods and expert systems for assessing criticality. The remote model states the methodology and expert information tool available at http://www.ni2cie.org/ CARVER2.asp. The fragment of it is on figure 1. In Czech Republic was created a tool for risk assessment marked CRITINFO. This expert information system occurs at the Technical University in Liberec and its fragment is presented on figure 2. 


\section{Criticality}

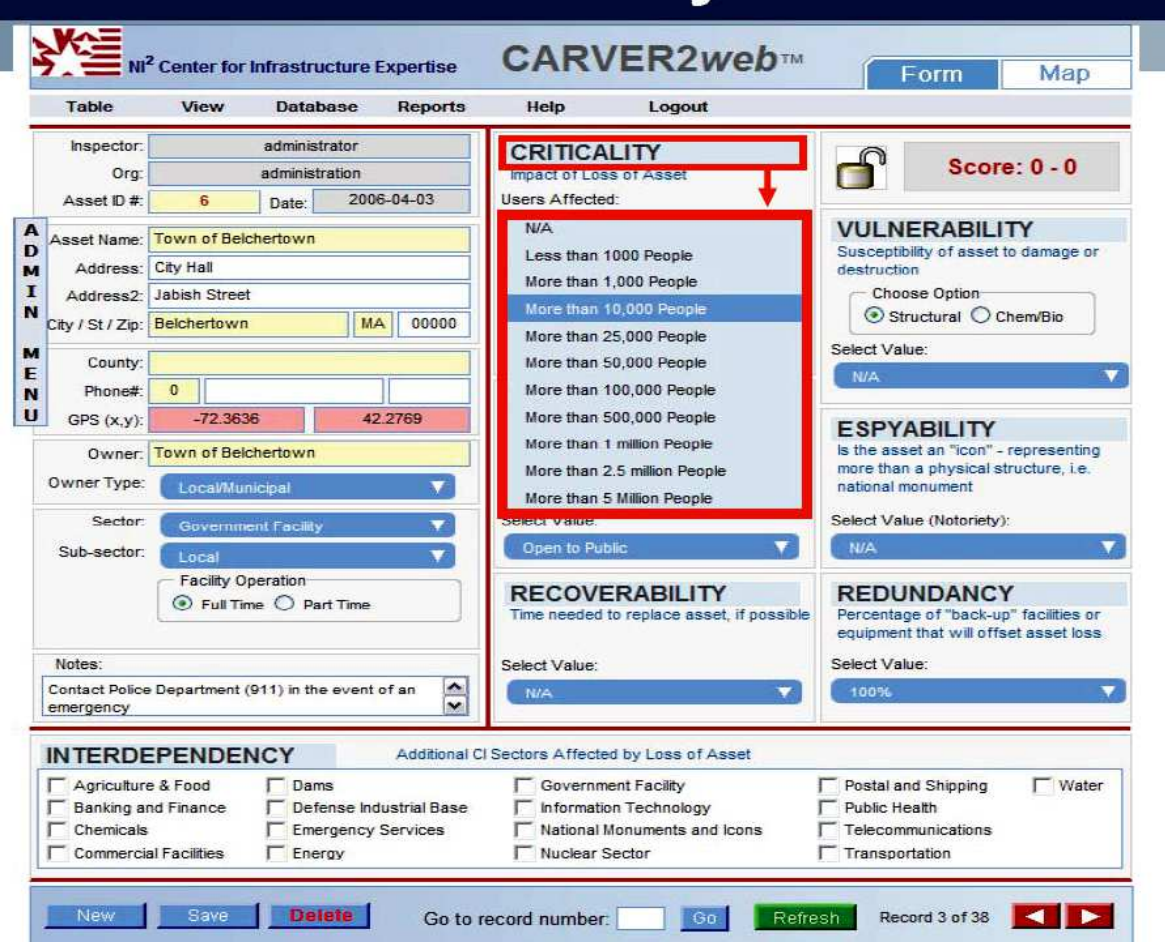

Figure 1: The window from CARVER2 - tools for defining criticism in critical infrastructure in Canada and the USA

Source: http://www.ni2cie.org/downloads/CARVER2web_demo.pdf

\section{Calculate Risk Event}

\begin{tabular}{|c|c|c|c|c|}
\hline \multicolumn{5}{|l|}{ Prováděné hodnocení } \\
\hline Typ infrastruktury Silniċni infrastruktura & Typ události Povodeň & & & \\
\hline Intenzita výskytu události & Náklady na obnovu & & Délka objiždky & \\
\hline Nová hodnota & Nová hodnota & & Nová hodnota & \\
\hline 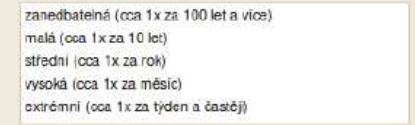 & 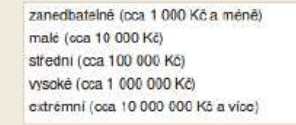 & & 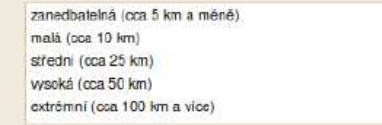 & \\
\hline Pívodní hodnota & Původni hodnota & & Původní hodnota & \\
\hline nehodnoceno & nehodnoceno & OK & nehodnoceno & OK \\
\hline Navižená hodnota & Navržená hodnota & & Navrżená hodnota & \\
\hline neni $\mathrm{k}$ dispozici & neni $k$ dispozici & OK & neni k dispozici & $\mathrm{OK}$ \\
\hline Intenzita dopravy & Doba do obnovy & & Vliv na zdraví a bezpečnost & \\
\hline Nová hodnota & Nová hodnota & & Nová hodnota & \\
\hline 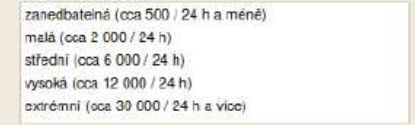 & 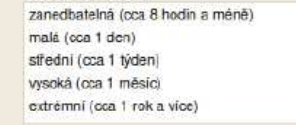 & & 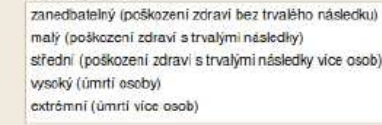 & \\
\hline Pîvodni hodnota & Pũvodni hodnota & & Původní hodnota & \\
\hline nehodnoceno & nehodnoceno & OK & nehodnoceno & OK \\
\hline Navržená hodnota & Navržená hodnota & & Navrżená hodnota & \\
\hline neni $k$ dispozici & neni $k$ dispozici & OK & neni k dispozici & OK \\
\hline
\end{tabular}

Figure 2: The window from CRITINFO - part calculate risk event (Havlíček, 2012) 


\section{SLOVAK APPROACH TO EVALUATION OF CRITICAL INFRASTRUCTURE}

Critical Infrastructure (next CI), an inherently complex field associated with the existence of each state. In view of the complexity of the system of internal self-sectors, but also the external links on each other more or less connected with other sectors of CI. This interaction is the result of direct or indirect links to other single industry sector. Due to the diversity of these links (direct or indirect), there is a wide range of risks that may arise as a chain reaction for activities in sectors as well as the entire CI. Breakdown of critical infrastructure is the sectoral structure defined by the Slovak Act č.45/2011 "of critical infrastructure." More is presented in Table 1.

Table 1: Sectoral breakdown of Slovakian critical infrastructure

\begin{tabular}{|c|l|l|}
\hline No & \multicolumn{1}{|c|}{ Sector } & \multicolumn{1}{|c|}{ Sub sector } \\
\hline 1. & Transport & $\begin{array}{l}\text { Road transport } \\
\text { Aviation } \\
\text { Water transport } \\
\text { Railway transport }\end{array}$ \\
\hline 2. & Electronic communication & $\begin{array}{l}\text { Satellite communication } \\
\text { Network and service fixed and mobile electronic } \\
\text { communications }\end{array}$ \\
\hline 3. & Energetic & $\begin{array}{l}\text { Mining } \\
\text { Electricity } \\
\text { Gas Industry } \\
\text { Petroleum and Petroleum Products }\end{array}$ \\
\hline 4. & $\begin{array}{l}\text { Information and Communication } \\
\text { Technologies }\end{array}$ & $\begin{array}{l}\text { Information systems and networks } \\
\text { Internet }\end{array}$ \\
\hline 5. & Postal & $\begin{array}{l}\text { The provision of postal, service, postal payment and } \\
\text { procurement activity }\end{array}$ \\
\hline 6. & Industry & Pharmaceutical, metallurgical and chemical industry \\
\hline 7. & Water and atmosphere & $\begin{array}{l}\text { Meteorological Service } \\
\text { Water works, provision of drinking water }\end{array}$ \\
\hline 8. & Health service & \\
\hline
\end{tabular}

Critical infrastructure is made up of individual sectors and elements. Summary of the elements of critical infrastructure sectors: "CI is designed according to the sectoral criteria and cross-cutting criteria", the element is: "in particular, the engineering construction of the $\mathrm{CI}$, the service in the public interest and the information system in the sector critical infrastructure whose disruption or destruction would have a serious adverse effect criteria according to the sectoral and cross-cutting criteria for the implementation of economic and social functions of the Slovak Republic, and thereby the quality of life of the inhabitants from the point of view of protection of their life, health, safety, property and the environment ". (Act No. 45/2011 ECR, p. 1)

For the definition of criticism infrastructure is necessary to take into account the cross-cutting criteria, which are designed in particular to:

- economic loss,

- the seriousness of the failure of the supply of goods,

- the seriousness of the failure of the provision of services in the public interest

\section{- (Act No. 45/2011 ECR, p. 3)}

For the calculation of the rates of criticism it is possible to be based on objective elements obtained from relevant sources (official statistics). As a supporting structure, it is appropriate to use quantitative methods in order to:

- obtain an average value of services provided,

- express the consequences of loss of the CI service sectors and sub sectors.

\section{ASSESSMENT OF SLOVAK CRITICAL TRANSPORT SUB SECTORS}

Each service provided by the user may be limited or interrupted, which may result in its purported. The calculations are based on the assumption that the service will be delivered in full and for the entire territory of the state within the sector. This assumption gives the possibility of finding the total volume and proportion of supplied services, as the basic unit of calculation. By Jasenovec (2011) individual calculations will be aimed at: 
Expression of the average loss of supply, service users,

$\mathrm{Ru}(\mathrm{t})$ - is the average number of persons, users of the services, supplies for the day

$\Sigma \mathrm{Ru}$ - is the total average number of persons, users of Ru-service $=864,438,000$

$\mathrm{T} \quad$ - is delivery time unit (365 days)

$$
\mathrm{Ru}(\mathrm{t})=\frac{\Sigma \mathbf{R u}}{\mathrm{t}}
$$

Real result is:

$$
\operatorname{Ru}(t)=864,438,000 / 365=2,368,323 \text { [pers./day] }
$$

The aim is to find out the average number of users, the calculation, who may be affected by the non delivering of the service such as: electricity, water, gas supply, electronic and voice services, the services associated with the transport of persons, goods, etc. Basis of calculation of the form the data obtained on numbers of users which are calculated from the average of the total numbers in those years. By calculation, we can get an overview of how many users, on average, uses the service for the time period of 24 hours.

Expression of the average financial loss of the supplies, services,

$\operatorname{Rf}(t)$ - is the average volume of sales for the supply, services per day

$\Sigma \mathrm{Rf} \quad-$ is the total average volume of sales for the supply, services in euros $=1,500,784,250$ eur

t $\quad$ - is a unit of time eur (365 days)

$$
\operatorname{Rf}(\mathrm{t})=\frac{\Sigma \mathbf{R f}}{\mathbf{t}}
$$

Real result is:

$$
\operatorname{Rf}(\mathrm{t})=1,500,784,250 / 365=4,111,738 \text { [eur/day] }
$$

The calculation is intended for obtaining the average value of the financial losses (revenue), which may be caused by the non delivering of the service such as: water, electricity, gas supply, electronic and voice services, the services associated with the transport of persons and goods, etc.

Express delivery services sector, sub-sector of the average loss of

Rds ( $t$ ) - is the average volume of transport, supplies, gas, electricity, etc. per day

$\Sigma$ Rds - is average volume of transport, the total supply of goods in the sector,

e.g. goods $=183,697,800 \mathrm{t}$
- is the time unit (365 days)

$$
\operatorname{Rds}(\mathrm{t})=\frac{\Sigma \mathrm{Rds}}{\mathrm{t}}
$$

Real result is:

$$
\operatorname{Rds}(t)=183,697,800 / 365=503,281.64 \text { [tons } / \text { day] }
$$

The average loss of the supply of services constitutes the expression of a value of the service sector in the delivery of goods, electricity, gas, etc. Underlying the calculation of the data is obtained from the average of the values in those years of supply. The result of these values is calculated for the time period of one day.

\section{Summary of example}

The above calculations show that the failure of the road transport sub-sector would result in potential loss of passenger traffic in the number of 2,368,323 persons in 24 hours. The consequence of this loss would be a weighting factor 0.944 to transport people across the transport sector. In financial terms, this loss would represent the value of 4,111,738 euros for 24 hours, with a weighting factor of 0.53 to the volume of the entire financial sector. The transport of goods would mean an average loss of volume 503281.64 tons, the weight, the transport of goods to the whole sector at 0.787. (Jasenovec, 2011, pp. 62-65)

\section{An example of the average financial loss of expression of selected services sectors}

First expression of the average financial loss for the carriage of passengers and goods by road

$$
\operatorname{Rf}(\mathrm{t})=1,500,784,250 / 365=4,111,738 \text { [eur/day] }
$$

Second expression of the average financial loss for the carriage of passengers and goods by rail

$$
\operatorname{Rf}(t)=962,902,250 / 365=2,638,088 \text { [eur/day] }
$$

Third expression of the average financial loss per passenger and cargo air transport

$$
\operatorname{Rf}(\mathrm{t})=317,880,500 / 365=870,905 \text { [eur/day] }
$$

4th expression of the average financial loss per passenger and goods by water transport

$$
\operatorname{Rf}(\mathrm{t})=41,888,000 / 365=114,762 \text { [eur/day] } .
$$




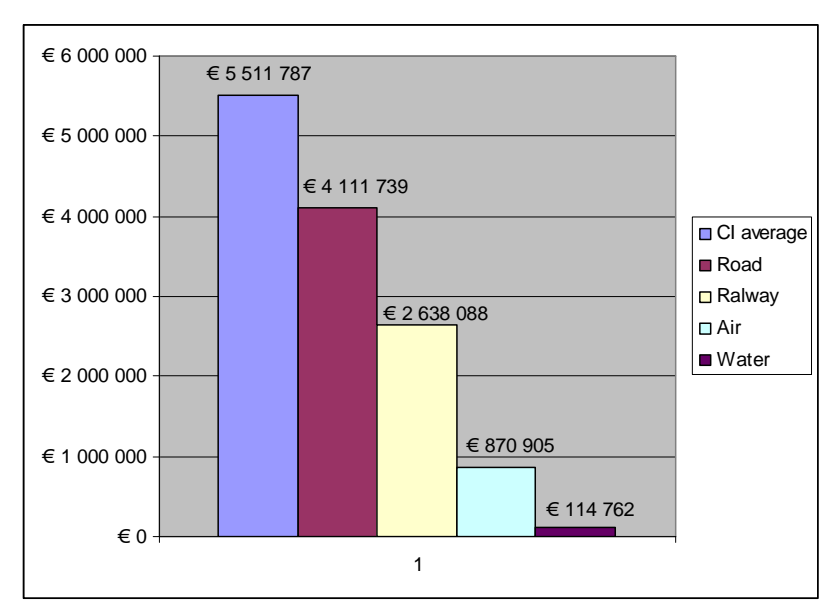

Figure 3: Average financial loss in Slovak critical transportation infrastructure sub sectors

The financial limit can also be used as a basis for calculation of time needed to reach the average loss (Figure 3). As an example, take the road transport sector, which was at $4,111,738$ euros. Substituting this sum together with the average financial loss of $5,511,787 / 4,111,738$, we find that the financial loss of road transport $=1.34$ which means that this sector has reached the limit of 1.3 per day. For comparison, the railway sector is similar 5,511,787/2,638,088, financial loss for railway compared with the average loss was achieved by 2.09 day.

\section{CONCLUSION}

Examination of the criticality of critical infrastructures in the world is in its infancy. There are numerous methods and procedures, the authors are only trying to add their own contribution to a mosaic of knowledge. The impact severity is reflected in the loss of service sector examined. This solution is possible when considering the various elements in the derived relations element to this indicator. This means that if the overall scale sector supplies a service, there is a relationship of individual elements of the supply or provision. At the same time it must be taken into account the importance of the element from the perspective of service delivery, that affects the sector such as the service:
- will be delivered to a limited extent in terms of time - short - long term,

- will be delivered in limited - region or throughout the state,

- not delivered at all,

- there is compensation for services.

Using this procedure, combined with measurable indicators, represents a possible way of defining criticality of infrastructure.

\section{REFERENCES}

Freight transport (Statistical data). Retrieved 16.1.2011 http://www.telecom.gov.sk/files/statistika_vud/prepra va_nakl.htm

Receipts for own performances and goods transport (in Slovak) (Statistical data). Retrieved 17.1.2011, from Slovstat http://www.statistics.sk/pls/elisw/casovy_Rad.procDlg

Transport - passenger transport: Comparsion of passenger transport by mode (Statistical data). Retrieved 16.1.2011

http://www.telecom.gov.sk/files/statistika_vud/prepra va_osob.htm

Zákon o kritickej infraštruktúre, č. 45/2011 Z. z. (Act No. 45/2011 ECR) C.F.R. (8. februára 2011).

The identification and designation of critical infrastructure and assessment of the need to improve their protection (in Slovak), č.787/ES C.F.R. (2006).

Havlíček, J. (2012) CRITINFO, developing expert information system (pp. The window from CRITINFO - part calculate risk event): Technical University of Liberec.

Jasenovec, J. (2011). Ochrana kritickej infraštruktúry. FŠI ŽU v Žiline, Žilina.

ni2cie. CARVER2® (pp. The window from CARVER2 tools for defining criticism in critical infrastructure in Canada and the USA): National Infrastructure Institute. Center for Infrastructure Expertise.

Zajíček, J. (2006). Hodnocení kritičnosti dopravní infrastruktury: TUL.

\section{ACKNOWLEDGEMENT:}

This work was supported by the Slovak Research and Development Agency under the contract No. APVV-0471-10 